${ }^{\circ}$ Entomologica Fennica. 19.X.1992

\title{
Braconidae (Hymenoptera) parasites of fungivorous Diptera in Karelia
}

\author{
E. B. Yakovlev \& V. I. Tobias
}

Yakovlev, E. B. \& Tobias, V. I. 1992: Braconidae (Hymenoptera) parasites of fungivorous Diptera in Karelia. — Entomol. Fennica 3:139-148.

A list of 18 species of Braconidae, 15 of the subfamily Alysiinae, reared from 65 mushrooms collected in the forests surrounding Petrozavodsk (Russian South Karelia) is given. Six new species are described by V. I. Tobias: Aspilota karelica sp. n., A. jakovlevi sp. n., A. fungicola sp. n., A. stigmatica sp. n., A. aequabilis sp. n., and A. spiritalis sp. n.

The most common probable hosts are larvae of Pegomya (Anthomyidae) and Megaselia (Phoridae).

E. B. Yakovlev, Forest Research Institute of the Karelian Centre of the Russian Academy of Sciences, Pushkinskaya 11, SU-185610 Petrozavodsk, Russia

V. I. Tobias, Zoological Institute of the Russian Academy of Sciences, Universitetskaya nab. 1, SU-199164, St. Petersburg, Russia

\section{Introduction}

During a study of fungivorous flies conducted in South Karelia in 1977-1987 numerous parasitic Hymenoptera were reared from fungal sporophores together with Diptera. Most of them were Braconidae of the subfamily Alysiinae. This material remained unpublished for almost ten years due to the little-known systematics of Alysiinae. The latter is the main reason for the fact that, although the Diptera community living as larvae in the sporophores of macrofungi has now been fairly extensively studied, its parasites have not yet received the attention they deserve.

Only relatively recent literature (Tobias 1986a, Wharton 1988, Van Achterberg 1988) indicates the considerable progress in the taxonomy of Alysiinae. It allows us to take the first step towards discovering the species composition of Braconidae connected with fungivorous Diptera in the European taiga. The present paper is based only on that part of the material collected in Karelia in which 6 new species of Aspilota were revealed. The list of non-braconid species reared from macrofungi will follow in a later paper.

\section{Material and methods}

Braconids were reared from 65 sporophores representing 22 species of macrofungi. The sporophores were collected in 1978, 1981 and 1982 at three localities in Soviet South Karelia (as it then was), i.e. the Kivach Nature Reserve $\left(62^{\circ} 17^{\prime} \mathrm{N}, 33^{\circ} 59^{\prime} \mathrm{E}\right)$, Vendjury $\left(62^{\circ} 11^{\prime} \mathrm{N}, 33^{\circ} 17^{\prime} \mathrm{E}\right)$ and Mashezero $\left(61^{\circ} 41^{\prime} \mathrm{N}, 34^{\circ} 18^{\prime} \mathrm{E}\right)$.

The traditional techniques of rearing have been fully described elsewhere (Yakovlev 1980a): sporophores with larvae were placed in containers (1-litre glass jars) on a layer of peat. These containers were covered with nylon gauze and kept outdoors in the shade. At the begining of December (after 
two-three weeks of frosty weather) the containers with hibernated larvae and pupae were gradually moved to room temperature and then kept in the laboratory. The insects appearing in the containers were caught with a pooter, then pinned or preserved in $70 \%$ alcohol.

Most of the collected Braconidae (including the type specimens) are stored in the Zoological Institute of the Russian Academy of Sciences (St.Petersburg). Duplicates and collections of Diptera are housed in the Forest Research Institute of the Karelian Centre of the Russian Academy of Sciences (Petrozavodsk).

\section{Results}

\subsection{The braconid fauna of the different species of fungi}

For each species of Braconidae the list gives the names of the fungal species from which it was reared and the names of possible hosts, viz., dipterous species reared from the same sporophores. The number of fungal sporophores from which each species of Braconidae was reared is given after the name of the fungus, and the numbers for the Diptera species after their names. The dates (months) of Braconidae rearings are indicated by Roman numerals.

Van Achterberg (1988), who revised the superspecific taxa of the Alysiinae found in mushrooms, concluded that the species of this group must be divided into several genera. However, he has not mentioned the well-recognized genus Synaldis, characterized by reduction of the first intercubital vein. Taking into account, firstly, that the genus Aspilota contains dozens of described and considerably more still undescribed species and secondly, that the characteristics which Achterberg used as generic criteria have not been well studied, it seems better to consider Dinotrema Foerst. and also Synaldis Foerst. still as the subgenera of the genus Aspilota.

\section{DORYCTINAE}

\section{Doryctes mutillator Thunberg}

Reared from Leccinum scabrum (1) together with Megaselia flava, Drosophila transversa, Muscina assimilis (VIII).

\section{BRACONINAE}

Bracon (Glabrobracon) pineti Thomson

Reared from Suillus luteus (1) together with Mycetophila fungorum, Drosophila transversa (VIII).

\section{EUPHORINAE}

Blacus (Blacus) exilis Nees

Reared from Boletus edulis (1) together with Tephrochlamys flavipes (IX).

AlysinAe

Alysia frigida Haliday

Reared from Leccinum scabrum (1), L. testaceoscabrum (2), L. vulpinum (1) together with Pegomya zonata (3), P. scapularis (1), P. flavoscutellata (1), Ula sylvatica (2), Corynoptera blanda (1), Bremia ciliata (1) (XII-II); from Thelephora terrestris (1) together with Mycomya sp. (1) (VIII).

\section{Alysia luciella Stelfox}

Reared from Leccinum vulpinum (3), L. testaceoscabrum (1) together with Pegomya zonata (2), P. tabida (1), P. pulchripes (1), P. flavoscutellata (1), P. incisiva (1), Mydaea discimana (1), Fannia ciliata (3), Ula sylvatica (3), Corynoptera sp. (1), Psychoda lobata (1) (XII-I).

\section{Anisocyrta perdita Haliday}

Reared from Leccinum scabrum (1) together with Pegomya scapularis, $P$. circumpolaris (I).

\section{Idiasta $\mathrm{sp}$.}

Reared from Russula sp. (1) together with Pegomya transversa, Mycetophila fungorum (XII).

\section{Phaenocarpa pratellae Curtis}

Reared from Leccinum scabrum (2), L. testaceoscabrum (3), L. vulpinum (1), L. aurantiacum (1) together with Pegomya scapularis (6), P. circumpolaris (2), P. incisiva (2), P. flavoscutellata (1), P. pulchripes (1), P. zonata (1), $P$. vittigera (1), Mydaea discimana (3), M. tincta (1), Fannia ciliata (1), Ula sylvatica (3), Limonia bifasciata (1), Trichocera saltator (1), Corynoptera blanda (1) (XII-II); from Boletus edulis (2), B. pinicola (2) together with Pegomya zonata (4), P. scapularis (1), Mydaea tincta (1), Ula sylvatica (1) (XII-I).

\section{Aspilota (Dinotrema) kempei Hedqvist}

Reared from Russula aeruginea (7), $R$. xerampelina (4), $R$. decolorans (2), $R$. nitida (1), $R$. emetica (1), R. paludosa 
(1), R. sp. (2) together with Megaselia rubescens (17), $M$. spinicincta (2), Mydaea setifemur (8), M. detrita (2), Pegomya geniculata (7), Ula sylvatica (5), Psychoda lobata 5), Mycetophila fungorum (5), M. strobli (4), Docosia gilvipes (1), Exechia contaminata (1), Drosophila transversa (4), Fannia difficilis (2), Cheilosia scutellata (1) (XII-II); from Agaricus arvensis (2) together with Megaselia rubella (2) (XII); from Lactarius rufus (1) together with Megaselia rubescens (I); from Suillus luteus (1) together with Megaselia rubescens (XII); from Kuehneromyces mutabilis (1) together with Megaselia rubescens (VIII); from Leccinum testaceoscabrum (1) together with Ula sylvatica, Mycetophila signatoides, Megaselia rubescens, Drosophila transversa, Pegomya flavoscutellata (XII).

\section{Aspilota (Dinotrema) sessilis Van Achterberg}

Reared from Russula aeruginea (1), Russula xerampelina (1) together with Megaselia rubescens (2), Alloeostylus diaphanus (1), Drosophila transversa (1), Mycetophila fungorum (1), Rondaniella dimidiata (1) (XII); from Lactarius necator (1) together with Megaselia rubescens (XII); from Kuehneromyces mutabilis (3) together with Megaselia rubella (3) (XII).

\section{Aspilota (Dinotrema) varimembris Fischer}

Reared from Kuehneromyces mutabilis (1) together with Megaselia rubella (VIII).

\section{Aspilota (Dinotrema) taurica Telenga}

Reared from Boletus pinicola (2) together with Megaselia rubescens (2), Suillia atricornis (1), Mydaea tincta (1), Bremia ciliata (1) (XII); from Agaricus arvensis (1) together with Megaselia rubella (XII); from Lactarius gluciosmus (1) together with Megaselia rubella (XII).

\section{Aspilota (Dinotrema) aequabilis Tobias, sp. n.}

Reared from Agaricus arvensis (1) together with Megaselia rubella, Ula sylvatica (XII).

\section{Aspilota (Dinotrema) fungicola Tobias, sp. n.}

Reared from Cortinarius sp. (1) together with Megaselia rubescens (XII).

\section{Aspilota (Dinotrema) stigmatica Tobias, sp. n.}

Reared from Kuehneromyces mutabilis (1) together with Megaselia rubella (XII).

\section{Aspilota (Aspilota) jakovlevi Tobias, sp. n.}

Reared from Lactarius necator (1) together with Megaselia rubescens, Suillia atricornis, Ula sylvatica (XII).
Aspilota (Aspilota) karelica Tobias, sp. n.

Reared from Russula aeruginea (1), R. xerampelina (1), $R$. paludosa (1) together with Megaselia rubescens (3), Mydaea setifemur (2), M. detrita (1), Alloeostylus diaphanus (1), P. geniculata (1), Drosophila transversa (2), Minilimosina fungicola (1), Allodia ornaticollis (1) (XII-I); from Lactarius rufus (1) together with Mydaea tincta, Exechia contaminata (XII-I).

\section{Aspilota (Synaldis) spiritalis Tobias, sp. $\mathrm{n}$.}

Reared from Russula aeruginea (1), R.vinosa (1) together with Megaselia rubella (2), Psychoda lobata (1), Corynoptera sp. (1.

\subsection{Connections between the braconids reared and their hosts}

It is not clear whether the Braconidae species mentioned are specialized on certain hosts, or whether they are non-selective, parasitising any species of larvae they meet in sporophores. The method of rearing, based on the use of the entire sporophore, does not permit precise designation of the hosts of parasites that have emerged in the containers, because several species of Diptera usually emerge from the same sporophore. However, the present material is suitable for some assumptions about host-parasite links of braconids and fungivorous flies.

All the 18 species of Braconidae reared from fungal sporophores can be easily divided into two groups. One of these is composed of three very polyphagous species whose host ranges are not restricted to dipterous larvae. Doryctes $m u$ tillator is known as a parasite of different species of xylophagous insects: Buprestidae, Cerambycidae, Curculionidae, Ipidae, Siricidae, Xyelidae, Tortricidae (Belokobylskii \& Tobias 1986). Blacus exilis also attacks Ipidae and Curculionidae larvae, living under the bark of conifers (Tobias 1986b). Bracon pineti is a parasite of wood-inhabiting larvae of Anobiidae and caterpillers of Geometridae and Tortricidae (Tobias 1986c). As a parasite of Laspeyresia strobilella L. it is well-known in Scandinavia and Central Europe (Bakke 1955). In Karelia the mortality of Laspeyresia caterpillars in spruce cones due to Bracon pineti may reach $28 \%$ (Yakovlev 1962). There is little data available on hatching these 
species from fungivorous insects. Hence, mushrooms do not appear to be a common habitat for them.

We have obtained these polyphagous parasites only in three containers with carpophores of Boletaceae together with several Diptera species reared without hibernation. Blacus exilis probably hatched from larvae of Tephrochlamys flavipes Zetterstedt (Helomyzidae), and the two other braconids from two or three other hosts reared together with them.

The second group is represented by 15 species of the subfamily Alysiinae belonging to the genera Alysia Latreille, Phaenocarpa Foerster and Aspilota Foerster. These species of Braconidae, in contrast to non-Alysiinae species, were represented by numerous specimens in containers, almost all of them reared from overwintered pupae.

The species of Diptera which fairly often emerged in the same containers with alysiins are given in Table 1. Other Diptera species were

Table 1. Numbers of mutual rearings of Alysiinae (Alysia, Phaenocarpa, Aspilota) and Diptera from the same fungal sporophore.

\begin{tabular}{lcrr}
\hline & Aly & Pha & Asp \\
\hline Pegomya (all species) & 7 & 11 & 8 \\
$\quad$ zonata (Zetterstedt) & 5 & 5 & - \\
scapularis (Zetterstedt) & 1 & 7 & - \\
geniculata (Bouché) & - & - & 8 \\
incisiva Stain & 1 & 2 & - \\
circumpolaris Ackland \& Griffiths & - & 2 & - \\
pulchripes (Loew.) & 1 & 1 & - \\
flavoscutellata (Zetterstedt) & 2 & 1 & 1 \\
tabida (Meigen) & 1 & - & - \\
vittigera (Zetterstedt) & - & 1 & - \\
Megaselia (all species) & - & - & 43 \\
$\quad$ rubescens Wood. & - & - & 32 \\
rubella (Schmitz) & - & - & 10 \\
$\quad$ spinicincta Wood. & - & - & 2 \\
Mydaea (all species) & 1 & 5 & 15 \\
$\quad$ setifemur Ringd. & - & - & 8 \\
tincta Zetterstedt & 1 & 2 & 4 \\
discimana Malloch & 1 & 3 & - \\
$\quad$ detrita Zetterstedt & - & - & 3 \\
Ula sylvatica Meigen & 3 & 4 & 8 \\
Drosophila transversa Fallén & - & - & 8 \\
Psychoda lobata Tonnoir & 1 & - & 6 \\
Mycetophila fungorum Degeer & - & - & 6 \\
M. signatoides Dziedzicki & - & - & 1 \\
Sporophores & & & \\
\hline & & 11 & 44 \\
\hline
\end{tabular}

reared from single sporophores and can therefore be ignored.

The species of the genus Phaenocarpa in general are known as parasites of larvae of higher flies (Cyclorrhapha) living in plant, fungal and animal tissues. Pegomya species (Anthomyiidae) are very often mentioned as hosts (Tobias 1986a). We reared Phaenocarpa pratellae from 11 sporophores of Boletaceae containing Pegomya larvae. In Leccinum sporophores the predominate species was Pegomya scapularis, in Boletus Pegomya zonata. There were also Mydaea flies (Muscidae) and Ula sylvatica (Limoniidae) reared from hibernated pupae, as well as Pegomya, although not from all sporophores which have produced Ph. pratellae. Thus, Pegomya larvae were the most probable hosts of this parasite and the latter does not seem to select certain species of Pegomya when searching for larvae inside the sporophore.

The same situation exists with Alysia species reared from 7 Leccinum sporophores together with Pegomya flies. But in this case there is one exception: a specimen of Alysia frigida was obtained from the container with Thelephora terrestris. These dry, tough sporophores are not used by Pegomya at all, but there were several mycetophilid larvae present on the lower surface of them. The adult gnats - Mycomya sp. soon emerged without hibernation together with their parasites, although other specimens of $A$. frigida were reared from overwintered Pegomya pupae.

Alysia frigida is the commonest parasite of Pegomya larvae in Leccinum sporophores (Hackman \& Meinander 1979). Relationships with Mycetophilidae are noted for the other Alysia species - A. sophia Hal. and A. tipulae Scop. (Tobias 1986a).

Aspilota species represent a group of endoparasites of the larvae of Phoridae occuring in decaying organic matter (including mushrooms) and Platypezidae in mushrooms (Van Achterberg 1988). Host records of mushrooms are given only by C. van Achterberg (1988). D. Luterek (1969) also reported catching several species of Aspilota: A. breviantenata Tobias, A. falsifica Stelfox \& Graham, A. fuscicornis Haliday, A. mandibularis Tobias on the sporophores of Russula, Agaricus, Boletus and Amanita.

In our rearings Aspilota species predomi- 
nated in species diversity, as well as in the number of reared individuals. In contrast to Alysia and Phaenocarpa species they were mostly reared from Russula (25 sporophores), Lactarius (6), Kuehneromyces (6) and Agaricus (4), while in Boletaceae they were mentioned only twice. The most probable hosts appear to be Megaselia flies (Phoridae), which have been reared from all sporophores where Aspilota were obtained regardless of the species of mushroom. The last was important only for the species composition of Megaselia: $M$. rubescens were mostly reared from Russula and Lactarius, whereas M. rubella emerged from Agaricus and Kuehneromyces. But Aspilota species as well as those of Phaenocarpa and Alysia did not discriminate between these two species of Megaselia.

It is noteworthy that fungivorous Megaselia species in Karelia have two generations a year, while those of Pegomya are usually mainly univoltine (Yakovlev 1988). Aspilota species, e.g. A. kempei, were reared from Megaselia larvae of the short-lived summer generation, hatching in summer, as well as from overwintered pupae belonged to the second generation.

\subsection{Description of new species of Aspilota}

\section{Aspilota (A.) jakovlevi Tobias, sp. n.} Fig. 1

Holotype: o, Karelia, Vendjury, from fungi [Lactarius necator (Bull.:Fr.) Karst.], 17.08.1982 (Yakovlev).

Closely allied to $A$. (A.) laevinotum Tobias; is different in short ovipositor and laterally compressed abdomen with longer 1st tergite.

Female. Body length $2.2 \mathrm{~mm}$. Head behind eyes is parallel-sided, only in posterior part of temples roundly narrowed, its width 1.75 times as long as length and 1.5 times as wide as mesoscutum width. Temples 1.3 times as short as eye. Ocelli are in isosceles triangle, base of which 1.5 times as short as distance between this base and eye. Distance between hind ocelli 1.5 times as long as diameter of ocellus. Tentorium areas extend over inner margin of eyes, tentorium pits very deep, occupy about 0.4 distance from pit to eye. Maxillary palpi long, nearly reaching middle coxae. Mandible slightly widening to-
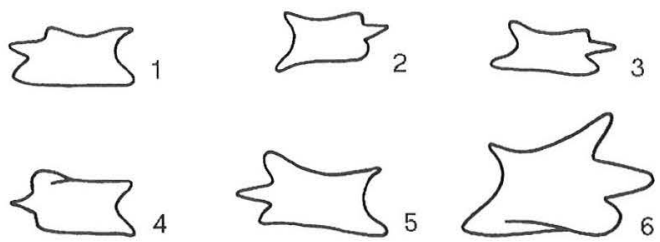

Figs. 1-6. Mandibles of Aspilota species. $-1 A$. (Aspilota) jakovlevi; 2 A. (A.) karelica; 3 A. (Synaldis) spiritalis; $4 A$. (Dinotrema) fungicola; $5 A$. (D.) stigmatica; 6 A. (D.) aequabilis.

wards apex, with more strongly developed blunted lower tooth; middle tooth pointed, upper tooth blunted, approximately half as long as lower. Antenna length is equal to body length, antennae thin, threadlike, consist of 20 flagellar segments with numerous hairs leaving obliquely, length of which is more than segment width; 1st flagellar segment 5 times, 2nd 3.5 times, middle and following 2.5 times as long as wide. 1st segment 1.twice as long as 2nd. Thorax length slightly more than its height $(55: 50)$. Mesoscutum without pit in front of anterior scutellum depression, notaulus in evidence only on its anterior border. Sternauli softly sculptured, narrow, reach anterior border of mesopleura. The distance between ends of sternauli and middle coxae is almost as long as the length of these coxae. Hind furrow of mesopleura smooth. Propodeum with weakly developed spiracles and 5-angled median cell, length of which slightly more than width; all carinae (transverse, outlining laterally median cell and longitudinal before it) very clear. Propodeum above transverse carina smooth, below it finely wrinkle-punctured. Hind femur 5,5 times as long as wide. Hind tarsus and tibia equal in length. Wings well developed; 2 nd portion of radial vein 4 times as long as 1st, 2.5 times as short as 3rd, twice as long as 1st radiomedial vein. Recurrent vein 1,5 times as short as posterior side of discal cell. Nervulus distally of basal vein by $1.5-$ twice its length. Abdomen flattened laterally, slightly longer than head and thorax together; 1 st tergite thin, weakly sculptured, with longitudinal carina at apical half, its length 3.5 times as long as apical width. Ovipositor direct, weakly and gradually widening towards apex, protruding in 0.6 length of 1 st abdominal tergite. 

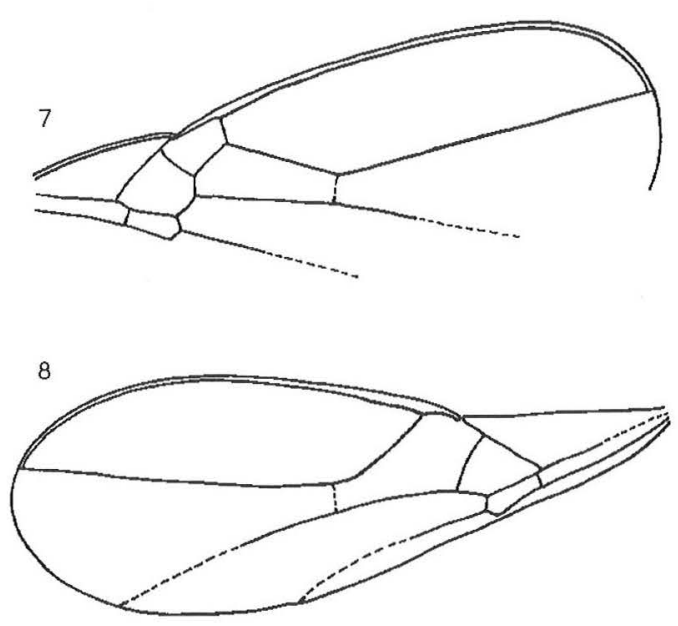

Figs. 7-8. Fore wings of Aspilota species. - 7 A. (A.) karelica; 8 A. (S.) spiritalis.

Head, thorax and most of antennae dark brown. Abdomen for the most part, and base of antennae, brown. Large spots on apical tergites and legs brownish-yellow, hind tibia in the apical third and 5-th tarsus segment darkened. Clypeus and mandibles yellow, palpi pale-yellow. Wings light, veins brown.

\section{Aspilota (A.) karelica Tobias, sp. n.}

Figs. 2, 7

Holotype:, , Karelia, Kivach Nature Reserve, from fungi (Russula sp.), 20.07.1982 (Yakovlev). - Paratypes: 1o, with holotype signs; 1o, Karelia, Vendjury, from fungi [Lactarius rufus (Scop.) Fr.], 11.08.1982 (Yakovlev), 10", Vendjury, from fungi (Russula aeruginea Lindbl.), 4.08.1982 (Yakovlev).

More closely allied to described $A$. (A.) jakovlevi sp. n.; is different in strongly elongated median cell of propodeum, short sternaulus, crenulated hind mesopleura furrow, absence of longitudinal carina at the 1st abdominal tergite.

Female. Body length 1.8-2.2 mm. Antennae with 18 segments, 1st flagellar segment 4 times, 2nd 3.5 times, 5-th and 6-th 3 times, following 2.5 times as long as wide; 1 st segment 1.1 times as long as 2nd. Sternauli short, end well before anterior border of mesopleura. Hind mesopleura furrow weakly crenulated. Propodeum with elongated median 5-angled cell, length of which nearly twice as long as its width; carinae outlining it as longitudinal carina in front of it and transverse propodeum carina weak. Hind femur 4.7 times as long as wide. 2 nd portion of radial vein 4-5 times as long as 1st, 2.3 times as short as $3 \mathrm{rd}$, twice as short as 1 st radiomedial vein. 1 st abdominal tergite without longitudinal carina. Ovipositor widened in the apical third. Base of antennae brownish-yellow. Abdomen even coloured, brown, 1st tergite slightly yellowish. Hind tibia even coloured, yellowish-brown.

Other characteristics as in A. (A.) jakovlevi.

Male. Body length $2.2 \mathrm{~mm}$. 1st abdominal tergite with weak longitudinal carina on posterior half.

\section{Aspilota (Synaldis) spiritalis Tobias, sp. n.} Figs. 3, 8

Holotype: $\circ$, Karelia, Kivach Nature Reserve, from fungi (Russula sp.), 9.08.1982 (Yakovlev). - Paratypes: 10 , the same signs, 20.07.1982 (Yakovlev); 2070', with holotype signs.

Differs from other Aspilota species with reduced radiomedial vein (Synaldis) and without median pit on mesoscutum, in very large propodeum spiracles. In this character it is similar to $A$. $(S$.) megastigma Fischer, but essentially differs in lack of median pit on mesoscutum, in considerably smaller width of ocelli triangle, in not rounded, only blunted lower mandible tooth, in longer hind femora, in considerably prolongated 1 st abdominal tergite and in short ovipositor.

Female. Body length $1.5-1.7 \mathrm{~mm}$. Head width 1.6 times as long as its length. Antenna with 15 segments; length of 1st flagellar segment 3.5 times, 2nd 2.5 times, middle and following 1.61.7 times as long as its width. Thorax length 1.3 times as long as its height. Sternaulus short, considerably removed from posterior border of mesopleura, as from anterior border. Hind mesopleura furrow weakly crenulated. Propodeum with large round spiracles, diameter of which is $0.75-1.0$ distance between spiracle and anterior border of propodeum; for the most part smooth, with clear transverse carina, more weak median carina (before transverse) and carina laterally outlining the median cell, nearly 4 -angled; 
median cell with fine wrinkled sculpture. Hind femur 4 times as long as wide. In fore wing 1 st radiomedial vein completely reduced, 1st portion of radial vein twice as short as 3rd. Recurrent vein 3 times as short as posterior side of discal cell. 1st abdominal tergite with two longitudinal carinae, its length 3 times as long as apical width. Ovipositor weakly upcurved, its length 0.5-0.7 times as long as 1st tergite length. Head black, thorax and abdomen brown; 1st-4th antennal segments, most of legs and 1st abdominal tergite yellowish-brown. Mandibles, coxae and trochanters yellow.

Other characteristics as in A. (A.) jakovlevi.

Male. Body length 1.7-1.9 mm. Antenna with 17-18 segments, which are more extended than female's segments: starting with 4 th it is $2-2.5$ times as long as wide. Spiracles of propodeum smaller, its diameter half the distance between spiracles and anterior border of propodeum.

\section{Aspilota (Dinotrema) fungicola Tobias, sp. n.} Fig. 4

Holotype: o, Karelia, Vendjury, from fungi [Kuehneromyces mutabilis (Fr.) Sing. et Smith.], 1978 (Yakovlev). - Paratypes: $10^{7}$ with holotype characters; 1 , Voronezh region, Khoper Nature Reserve, $12 \mathrm{~km}$ downstream along the Khoper river from v. Varvarino, forest, 7.07.1977 (V.Tobias).

Closely allied to $A$. (D.) oleracea Tobias; is different in longer ovipositor, visibly thicker antennae with more short segments and greater number of these, and more rough sculpturing of propodeum.

Female. Body length 1.7-2.1 mm. Head 1.4 times as wide as mesoscutum, 1.7 times as wide as long, behind eyes roundly narrowed. Temples 1.5 times as short as eyes. Ocelli form an iscoceles triangle, base of which is equal to distance between this base and compound eye. Distance between hind ocelli twice as long as diameter of ocellus. Malar space behind lower margin of eye with short oblique furrow. Tentorium pits occupy nearly 0.4 of distance between pit and eyes, tentorium fields not developed. Mandibles almost parallel-sided, twice as long as wide, upper and lower teeth small, rounded, considerably less than middle, pointed tooth. Antennae slightly longer than body, consisting of 20-22 moniliform segments, 1st segment 3.5 times, 2nd 2.5 times, middle 1.5 times, apical 1.3 times as long as wide. Flagellum with numerous hairs obliquely inserted, length of these being nearly equal to segment width. Thorax length slightly greater than its height. Mesoscutum before the anterior scutellum depression with short median pit, notauli are evident only in front. Sternauli sculptured, reach or almost reach (in paratype) anterior border of mesopleura, do not reach middle coxa by almost as much as length of one sternaulus from behind. Hind mesopleura furrow smooth. Propodeum with small spiracles, roughly wrinkled with unclear 5-angled cell in the middle, divided by longitudinal carina (not developed in paratype). Upper part of propodeum more weakly sculptured, glittering, separated from its lower part by fracture in the middle obliquely lowered transverse. 2 nd portion of radius 3.5 times as long as 1st, 2.5 times as short as 3rd, twice as long as radiomedial vein. Recurrent vein 1.4 times as short as posterior side of discal cell. Nervulus weak distally of basal vein. Hind femur 4 times as long as wide. Abdomen shorter than head and thorax together $(65: 80)$. 1st tergite irregularly wrinkled without clear spiracle tubercle, its length 1.7 times as long as apical width. Ovipositor upcurved, its sheath length equal to abdomen.

Body black; 1st tergite redish-brown. Palpi, scapi and legs brownish-yellow. Wings bright, veins brown.

Male. Body length $2.1 \mathrm{~mm}$. Antennae with 21 segments, slightly longer than the female ones, with longer segments: segments in the middle of flagellum nearly twice, in the apex 1.5 times as long as wide.

\section{Aspilota (Dinotrema) stigmatica Tobias, sp. n.} Fig. 5

Holotype:, , Karelia, Kivach Nature Reserve, from fungi [Kuehneromyces mutabilis (Fr.) Sing. et Smith.], 14.07.1982 (Yakovlev). — Paratype: 1o, West Caucasus, Sochi (Lazarevskoje), forest near stream, 4.05.1979 (V.Tobias).

Resembles A. (D.) erythropa Foerst. by comparatively large, outstanding spiracles of propodeum, but differ in extremely smaller size, 
considerably less number of flagellar segments, and moreover almost non-pubescent mesoscutum; weak, but clear tooth-like projections in upper part of temples. In last character is a step towards to $A$. (D.) kempei Hedqv., but differs from this in mandibles considerably widened towards apex with pointed upper tooth going away, in shorter flagellar segments, in strongly developed propodeum spiracles, in abdomen not depressed laterally and with shorter 1 st tergite.

Female. Body length 1.7-1.8 mm. Head in upper part of temples with small obtuse-angled projection (weak in paratype); head 1.6 times as wide as long, 1.6 times as wide as mesoscutum width. Temples 1.2 times as short as eyes. Malar space with oblique furrow, lowered to anterior margin of mandible base. Mandibles slightly widened towards apex, upper and middle teeth almost equal in length, middle pointed, upper blunted, lower least, rounded in apex. Antennae slightly shorter than body, consist of 18-19 moniliform segments, 1 st segment 3 times as long as wide, 1.2 times as long as 2 nd. 2 nd and following segments 1.5-1.3 times as long as wide, segments in the apical part of flagellum slightly longer than before it. Steraulus short, not reaching anterior border of mesopleura. Propodeum spiracles rather large, located away from its anterior border by 3 times its diameter. Propodeum smooth, with wrinkly sculptured strip in the middle, but without expressed longitudinal carina. 2nd portion of radius $4-4.5$ times as long as 1 st, 2.2-2.7 times as short as 3rd. Recurrent vein twice as short as posterior side of discal cell. Abdomen slightly shorter than head and thorax together, laterally contracted; 1st tergite irregularly wrinkled, its length twice as long as apical width. Ovipositor sheath and hind femur are equal in length.

Body black, abdomen dark brown. Base of scapi yellowish. Legs mostly brown. Palpi, mandibles, front, middle and base of hind coxae, all trochanters yellow. Wings weakly darkened.

Other characteristics as in A. (D.) fungicola.

\section{Aspilota (Dinotrema) aequabilis Tobias, sp. n.} Fig. 6

Holotype: , Karelia, Vendjury, from fungi (Agaricus arvensis Schaeff.:Secr.), 13.08.1982 (Yakovlev).
Closely allied to $A$. (D.) pratensis Van Achterberg; differs in interstitial nervulus, in extremely short, shorter than 2nd, 1st flagellar segment, in sternaulus elongated in anterior part, transverse sculptured strip on propodeum.

Female. Body length $2.1 \mathrm{~mm}$. Head 1.3 times as wide as long. Temples 1.2 times as short as eyes. Tentorium pits large, occupy nearly 0.5 distance from pit to eye. Mandibles short, widened towards apex, with going away upper tooth; upper tooth apically rounded, middle outstanding moderately pointed, lower tooth widely rounded. Antennae consist of 22 segments; flagellar segments twice as long as wide, except 1 st, length of which 1.8 times as long as its width. Flagellum with numerous suberect hairs, length of which is nearly equal to 0.5 segment width. Thorax 1.3 times as long as high. Sternauli long, reach anterior border of mesopleura. Propodeum without clear carinae and cells, with longitudinal median wrinkled sculptured strip, in its upper third with transverse wrinkled punctured strip, on the other surface with smooth sculpturing, glittering. 2nd portion of radius 3.5 times as long as 1st, 2.3 times as short as 3rd. Recurrent vein 2.5 times as short as posterior side of discal cell. Nervulus opposite basal vein. Abdomen shorter than head and thorax together (6:7), laterally compressed; 1st tergite with outstanding spiracle tuberculi, its length 2.5 times as long as apical width.

Head and thorax black, abdomen and antennae dark brown. Scapi, mandibles and legs brownishyellow. Tegula yellowish-brown. Tarsi of all legs darkened.

Other characteristics as in A. (D.) fungicola.

\section{Discussion}

The study of the predators representing the highest trophic level of the insect communities connected with macrofungi is of great interest to both systematic and ecological entomology. The former is due to the fact that the species composition of several groups of these predatory insects are fairly unknown. The main difficulty in preparing this paper was the identification of Aspilota, because the material contained several new species (cf. Achterberg 1988). The latter is of particular in- 
terest due to the considerable role these groups of predators play in forest ecosystems. Numerous predators, such as some Muscidae, Staphylinidae, etc, inhabit fungal sporophores. Moreover, fungivorous larvae represent an extensive food supply for surface-active predators - spiders, carabids, and ants - which, as we noted, in Cladonia pine forests (unpublished data) in autumn concentrated around the large sporophores of Boletaceae. The special behaviour of fully-fed larvae of Mycetophilidae in jumping out from the hymenophore of fruiting bodies, and of Pegomya larvae which endeavour to go down into the mineral layer of the soil to pupate, can be considered as adaptations for avoiding predators (Eisfelder 1955; Yakovlev 1980b). Predation may inflict up to $90 \%$ mortality on Pegomya larvae and pupae (Ståhls et al. 1989).

Parasitic Hymenoptera have been found to be the third group of natural enemies of fungivorous Diptera. In order to estimate the role of mushrooms as a direct food supply for parasitoid wasps it would be useful to bear in mind the results of Yakovlev (1988) showing that species feeding on fungal sporophores and mycelia form a large part of the Diptera of boreal forests. The occurence of parasitic Hymenoptera in mushrooms, e.g. in Leccinum, varies from year to year (Ståhls et al. 1989), and in some years they can be observed with great frequency. Thus, of hundreds of Leccinum sporophores examined in 1983 (Yakovlev \& Osipova 1985) 39\% contained the highly characteristic flat galleries mined by alysiins.

Alysiinae, the main group of parasitic Hymenoptera occurring in fungal sporophores, are represented by the species which appear to be specialized on a particular host-species among fungivorous Diptera. This specialization is not obligate - the exception of A. frigida confirms it. And the pattern of alysiiin specialization on dipterous hosts resembles those of fungivorous flies on their host fungi. In both cases a consumer is able to use not only single species of hosts but a whole range of species of the same genus closely related ecologically.

To locate their host, Alysiinae parasitic on fungivorous Diptera must first of all find the mushroom in which their larvae can live. Hence, when searching for hosts these alysiins probably orient to similar signals to their dipterous hosts, and these signals are provided by fungal sporophores.

However, the results of the experiments on the attraction of these insects by fungal sporophores and their volatile compounds carried out by the author Yakovlev (publication in part deals with Diptera, Yakovlev \& Myttus 1989) do not support this assumption. Braconids were attracted to the traps with fungal baits but they were not as numerous as Diptera. Moreover, traps of the "Atracon"-type enclosing fungal sporophores were considerably less successful than gluecoated glass plates standing close to the open sporophores. Furthermore, the greatest attraction for braconids, regardless of the bait used, were the flat red or yellow plastic traps looking like yellow Merike cups. At the same time artificial mixtures of aromatic substances from mushrooms were less attractive to braconids than they were to fungivorous Diptera. These facts permit us to hypothesise that visual stimuli are more important to parasitic Hympenoptera than to their dipterous hosts.

The most significant primary fungivorous flies in taiga forests are the range of species of Mycetophilidae, Bolitophilidae, Pegomya, Megaselia and Suillia. The origin of each of these groups was correlated with the use of fungal sporophores as food and a habitat for the larvae. Rearing experiences (Hackman \& Meinander 1979; Yakovlev \& Osipova 1985; etc.) show that different species of macrofungi are apparently divided between these groups of Diptera. Mycetophilidae occupy many species of Agaricales s.l. and some Aphyllophorales with more or less soft sporophores. Anthomyiidae prefer Boletaceae, and Phoridae Agaricus, Russula, some Lactarius species, and a range of mushrooms appearing in spring, e.g. Pezizales, Kuehneromyces etc., while Helomyzidae more readily attack some Lactarius and Cortinarius species. If the presumption of host-specialization of Alysiinae is correct, all these groups of fungivorous Diptera must have their own parasitic species. However, we have not found any such group of Alysiinae parasitizing Mycetophilidae and Suillia flies. Relationships between these fungivorous flies and parasitic Hymenoptera can be expected, but possibly in this case Alysinae are not the 
most significant parasites. The further development of this topic is of interest in regard to the study of evolution in Braconidae because the groups of fungivorous gnats and flies mentioned above appeared and gradually developed at different times and in different stages of the historical development of Diptera.

Acknowledgments. We are grateful to Dr. A. N. Naumov (Serpukhov, Moscow district) for the identification of Megaselia species.

\section{References}

van Achterberg, C. 1988: The genera of the Aspilotagroup and some descriptions of fungicolous Alysiini from the Netherlands (Hymenoptera: Braconidae: Alysiinae). - Zool. Verh. Leiden 247:1-88.

Bakke, A. 1955: Insects reared from spruce cones in northern Norway. - Oslo. 212 pp.

Eisfelder, I. 1955: Die häufigsten Pilzbewohner, (Fortzetzung). - Zeitschr. Pilzkunde 21:12-20.

Hackman, W. \& Meinander, M. 1979: Diptera feeding as larvae on macrofungi in Finland. - Ann. Zool. Fennici 16:50-83.

Luterek, D. 1969: Entomofauna owocnikow niektorych gatunkow lesnych grzybow kapeluszowych. — Prirod. Kom. Nauk Roln. Lesn. Poznan TPN 28:185-230.

Ståhls, G., Ribeiro, E. \& Hanski, I. 1989: Fungivorous Pegomya flies: spatial and temporal variation in a guild of competitors. - Ann. Zool. Fennici 26:103112.

Tobias, V. I. (Тобиас, В. И.) 1986a: [22. Subfamily Alysiinae.] (In Russian) — In: Tobias, V. I., Belokobylskii, S. А. \& Kotenko, А. G. (Тобиас, В. И., Белокобыльский, С. А. \& Котенко, А. Г.) (eds.), [Guide to the insects of the European part of the USSR. 3. Hymenoptera] 5:100-231. Leningrad.

- 1986b: [8. Subfamily Euphorinae.] (In Russian) - In: Tobias, V. I., Belokobylskii, S. A. \& Kotenko, A. G. (Тобиас, В. И., Белокобыльский, С. А. \& Котенко, A. Г.) (eds.), [Guide to the insects of the European part of the USSR. 3. Hymenoptera] 4:181-250. Leningrad.
- 1986c: [4. Subfamily Braconinae.] (In Russian) - In: Tobias, V. I., Belokobylskii, S. A. \& Kotenko, A. G. (Тобиас, В. И., Белокобыльский, С. А. \& Котенко, A. Г.) (eds.), [Guide to the insects of the European part of the USSR. 3. Hymenoptera] 4:94-149.

Tobias, V. I. \& Belocobylskii, S. А. (Тобиас, В. И. \& Белокобыльский, С. А.) 1986: [22. Subfamily Alysiinae.] (In Russian) - In: Tobias, V. I., Belokobylskii, S. A. \& Kotenko, A. G. (Тобиас, В. И., Белокобыльский, С. А. \& Котенко, А. Г.) (eds.), [Guide to the insects of the European part of the USSR. 3. Hymenoptera] 4:21-72. Leningrad.

Yakovlev, В. Р. (Яковлев, Б. П.) 1962: [The Spruce-cone Tortrix (Laspeyresia strobilella L.) injuring cones and seeds of spruce in Karelia.] (In Russian) - In: [Problems of forestry and forest entomology in Karelia.] 1962:106-112. Moscow, Leningrad.

Yakovlev, Е. В. (Яковлев, Е. Б.) 1980a: [On the fauna of Diptera associated with macrofungi in Karelia.] (In Russian) - In: Kozlovskaya, L. S. \& Krutov, V. I. (Козловская, Л. С. \& Крутов, В. И.) (eds.), [Entomofauna and pathogenical mycoflora in forest ecosystems of Karelia and Murmansk district.] 1980:4560. Acad. Sci. USSR, Karelia, Petrozavodsk.

- 1980b: [Succession of trophic groups of larvae of diptera in fruit bodies of mushrooms.] (In Russian) Dokl. Acad. Sci. USSR. 253(2):506-509.

- 1988: [Fungal productivity and seasonal flight activity of Diptera in young pine and aspen forests.] (In Russian) - Petrozavodsk. 68 pp.

Yakovlev, E. B. \& Myttus, E. R. 1989: On the attraction of insects by the fungal sporophores and by some fungal smell constituents. (In Russian with English summary) — Petrozavodsk. 48 pp.

Yakovlev, E. B. \& Osipova, L. T. (Яковлев, Е. Б. \& Осипова, Л. Т.) 1985: [Species composition and bioecological features of insect-inhabitants of the reproductive parts of edible fungi in southern Karelia.] (In Russian) - In: Shubin, V. I. \& Krutov, V. I. (Шубин, В. И. \& Крутов, В. И.) (eds.), [Insects and phytopathogenic fungi in forest ecosystems.] 1985:471. Acad. Sci. USSR, Karelia, Petrozavodsk.

Wharton, R. A. 1988: The braconid genus Alysia (Hymenoptera): a revision of the subgenus Anarcha. Contr. Amer. Entomol. Inst. 25(2):1-69.

Received 2.IV.1991 